\title{
Projeto para uma Psicologia Cientifica: máquina falante ou fala maquinal?
}

OSMYR FARIA GABBI JUNIOR

O "Projeto para uma Psicologia Científica" (1950[1895]) tem como objetivo explícito "representar os processos psíquicos como estados quantitativamente determinados de partículas materiais especificáveis". ${ }^{1}$ Esta forma de apresentação estaria justificada por possibilitar a exposição de uma psicolọgia precisa e livre de contradições, na qual os conceitos fundamentais são os de quantidade e de neurônio. Como um leitor atento de Freud sabe, quantidade e neurônio já haviam aparecido inúmeras vezes na obra freudiana sob as espécies de excitação e representação respectivamente. No presente trabalho defenderemos a tese de que no "Projeto" há a tentativa de construir-se uma teoria do aparelho psíquico que dê conta das descobertas clínicas e confira apoio dedutivo ao método psicanalítico utilizado no tratamento das neuroses de defesa. A linguagem mobilizada pelo texto de Freud será progressivamente relativizada, mostrando o seu caráter metafórico, mas nem por isso menos importante. Trata-se, em suma, para Freud, de explorar todas as conseqüências que podem ser retiradas, com proveito, de uma hipótese fundamental a respeito do funcionamento do aparelho psíquico.

Quantidade é definida como uma diferença entre atividade e repouso, submetida a leis gerais do movimento, e neurônio como

(1) Freud, S. "Projeto para uma Psicologia Científica" (abreviado neste trabalho por "Projeto"). ESB, p. 395; SE, p. 295. 
uma partícula material capaz de conter uma certa quantidade. ${ }^{2} \mathrm{~A}$ concepção de quantidade foi sugerida pela observação clínica de pacientes apresentando neuroses de defesa "onde a característica quantitativa emerge com maior clareza do que nas condições normais". ${ }^{3}$ A constatação da presença do fator quantitativo leva a postular um princípio, o princípio da inércia neuronal - "os neurônios tendem a descarregar uma quantidade Q" - cujo papel é o de constituir fundamento para explicar: ${ }^{4}$

a) a estrutura dos neurônios;

b) o desenvolvimento do sistema neuronal;

c) a função do sistema neuronal.

A estrutura neuronal é funcionalmente dicotômica: os neurônios podem ser sensoriais ou motores, dependendo de se recebem ou descarregam, respectivamente, uma certa quantidade neuronal. A divisão é fundamentada pelo princípio da inércia aplicado ao sistema neuronal como um todo: qualquer excitação que atinge o sistema através dos neurônios sensoriais é imediatamente descarregada pelos neurônios motores, de modo a mantê-lo em estado de repouso, portanto, por definição sem Q. ${ }^{5}$

O sistema nervoso primário se desenvolve através da recepção e descarga de Q'n (quantidade presente no sistema neuronal) pela ação conjunta dos neurônios sensoriais e motores, ligados ao sistema muscular. O objetivo é manter Q'n afastada do sistema nervoso, ou seja, realizar a função primária dos neurônios. ${ }^{6}$

No entanto, além da função primária, há uma função secundária que consiste em reter os caminhos de descarga que se tornaram preferenciais por acarretarem uma interrupção do fluxo de Q'n. Em outras palavras, deve surgir no sistema um mecanismo de reten-

(2) Ibid. , ESB, p. 395; SE, p. 295. Na verdade, o "Projeto" pode ser construido em torno de uma única tese: todos os processos psiquicos podem ser descritos como diferenças quantitativas. O próprio conceito de neurônio pode ser, sem muito esforço, subsumido a essa tese.

(3) Ibid., ESB, p. 396; SE, p. 295. Para Freud, o patológico revela sempre os elementos presentes no normal de uma forma ampliada e isolada. Funciona como uma espécie de química qualitativa que isolaria os elementos que usualmente se encontram associados.

(4) Ibid., ESB, p. 396; SE, p. 296. Todo o texto do "Projeto" pode ser visto como uma grande tentativa, parcialmente frustrada, de mostrar que qualquer processo psiquico pode ser visto como uma dedução do postulado da inércia.

(5) Ibid., ESB, pp. 396-397; SE, p. 296.

(6) Ibid., ESB, p. 397; SE, p. 296. 
ção de modo que ele possa realizar um trabalho de manutenção dos "caminhos favoritos". ?

Evidentemente a constituição dos caminhos está de acordo com o postulado da inércia. Contudo, o estabelecimento de uma preferência já supõe que haja diferenças dentro do sistema neuronal: elas vão servir como "indicadores" dos caminhos preferenciais. Freud supõe um segundo postulado, o postulado da constância: os neurônios tendem a manter constante uma certa quantidade de Q'n. ${ }^{8}$ Mas se os estímulos externos não transgridem o postulado da inércia - a quantidade que entra é igual à gasta para afastar um estímulo que se originou no mundo externo - por que se torna necessário reter os caminhos de descarga? Por que se vai conceber, além do postulado da inércia, o postulado da constância?

A razão, segundo o texto, está nos estímulos internos, nas "exigências da vida." ${ }^{9} \mathrm{O}$ aumento da complexidade do organismo acarreta o surgimento de estímulos endógenos, suas células dão "lugar a grandes necessidades: fome, respiração, sexualidade”. Aqui não há mais relação de igualdade entre o que entra e o que sai do sistema neuronal. Os estímulos endógenos, diferentemente dos externos que atuam por impacto, vão-se somando. Só há uma interrupção no trabalho de somação quando o organismo produz uma "ação específica" sobre o mundo externo; ou seja, é preciso alterar as condições do mundo externo para produzir uma modificação no mundo interno - a suspensão provisória do processo de somação. A relação entre o gasto decorrente da modificação do mundo externo e o ganho de quantidade através do processo de somação não é a de identidade. ${ }^{10}$ Por outro lado, também seria absurdo pensar que o mundo externo estará sempre em condições ideais para que a ação específica possa ser produzida. Portanto, o sistema nervoso deve aprender a suportar uma certa quantidade neuronal de modo a conservar os caminhos preferenciais de descarga, para que possa constituir um mecanismo de retenção.

Por conseguinte, chegamos à conclusão de que há duas fun-

(7) Ibid., ESB, p. 397; SE, p. 296.

(8) Ibid., ESB, p. 398; SE, p. 297.

(9) Ibid., ESB, pp. 397-398; SE, pp. 296-297.

(10) Ibid., ESB, p. 397; SE, p. 297. Causa estranheza o aparecimento da respiração entre as grandes necessidades da vida. Pois, a ênfase está nas necessidades que para serem satisfeitas exigem a realização de uma ação específica: uma modificação apropriada nas condições externas. 
ções no sistema neuronal: a de descarregar quantidades (função primária) e a de conservar os caminhos preferenciais de descarga (função secundária), ou seja, a ação específica. Se a primeira está ligada ao externo, ao que não é ainda vivo - um retorno ao estado inicial de inércia - na segunda, assinala-se a necessidade de se introduzir a memória como conseqüência dos imperativos internos, da própria vida.

A teoria neuronal parte do pressuposto de que todos os neurônios são idênticos entre si e de que cada neurônio isoladamente é um modelo do sistema neuronal. Em outras palavras, cada neurônio é composto de uma parte sensorial que recebe as quantidades, chamada "dendritos", e de uma parte motora que descarrega as quantidades e termina numa "barreira de contato" (resistências que impedem a passagem de uma quantidade neuronal). O fluxo das quantidades, de acordo com o modelo proposto, vai da parte sensorial para a parte motora, sendo que as vias de recepção são inúmeras, enquanto a descarga é única, dando-se através de um eixo chamado axônio. ${ }^{11}$ Portanto, o modelo neuronal pode ser visto como formado pela conjunção de dois neurônios: um sensorial e o outro motor. O que mostra de imediato por que o princípio da inércia serve de fundamento para explicar a estrutura neuronal: tudo que entra (sensório), sai (motor). A postulação das barreiras de contato, exigida pela natureza da própria vida, leva à necessidade de passar-se desse princípio para o da constância. Se essas barreiras não existissem, a quantidade que entrasse em um neurônio sairia imediatamente, mantendo a inércia neuronal.

Se partimos da hipótese de que as quantidades externas são muito maiores do que as geradas internamente, teremos que os neurônios em contato com os órgãos do sentido, neurônios sensoriais, estão sob a ação de uma quantidade muito maior do que a resistência oferecida pelas barreiras de contato; eles são totalmente permeáveis à passagem de uma quantidade. A permeabilidade total os torna capazes de representar adequadamente a sensação, uma vez que, passado o fluxo de quantidade, eles voltam ao estado anterior: $:^{12}$ são chamados de neurônios fi. Eles não violam o princípio da inércia. Por sua vez, nos neurônios em contato com os estímulos endógenos, a quantidade sendo, por hipótese, muito menor, da mesma magnitude que as barreiras de contato, torna-os muito pouco permeá-

(11) Ibid., ESB, p. 398; SE, p. 298.

(12) Ibid., ESB, p. 405; SE, p. 304. 
veis. ${ }^{13}$ Portanto, dada a passagem de uma certa quantidade, apenas os neurônios que tenham uma resistência menor do que a quantidade que incide sobre eles serão carregados com Q'n, ou seja, serão catexizados. ${ }^{14}$ Daí o fato do sistema neuronal poder reter caminhos preferenciais. Aquelas vias que forem mais vezes repetidas ou percorridas com intensidades maiores acarretaram menor resistência nesses neurônios de modo que na próxima vez que passar uma nova quantidade, eles serão de novo catexizados. Por conseguinte, o modelo neuronal proposto pode servir de modelo para um mecanismo de retenção de vias preferenciais baseado nas diferenças de facilitação existentes entre os neurônios. Como a facilitação é função da quantidade neuronal retida pelo neurônio, é evidente que esse sistema, denominado psi, contraria o princípio da inércia neuronal e se submete ao da constância. Logo, como já havíamos sugerido acima, as exigências da vida requerem também a existência de um aparelho da memória. No entanto, permanece a questão acerca do que ocorre no encontro entre o sistema fi e psi.

Sabemos que as quantidades em fi são maiores do que em psi e que por definição não há nenhuma diferença morfológica entre os neurônios. De que modo se dá a modificação de quantidade na passagem de um sistema para o outro? A solução freudiana consiste em pensar que o número de neurônios psi é muito maior do que o de neurônios fi; ou seja, um neurônio fi está em contato com muitos neurônios psi de modo que a quantidade que atinge cada neurônio psi já é da magnitude da sua barreira de contato. ${ }^{15}$

O sistema nervoso, assim constituído, nos ensina que nem toda quantidade que chega a fi passa por psi, pois uma parte já é desviada para o aparelho muscular. ${ }^{16}$ Por outro lado, o sistema psi é composto de dois grupos de neurônios, os em contato com fi, denominados psi do pallium, e os em contato com os estímulos endógenos, psi do núcleo. ${ }^{17}$

(13) Ibid., ESB, p. 405; SE, p. 304.

(14) Ibid., ESB, p. 405; SE. p. 304. A diferença entre quantidade interna e a externa é fundamental na constituição do aparelho psíquico e na realização das suas diversas funçōes.

(15) Ibid, , ESB, pp. 417-419; SE, pp. 314-315. A estratégia de Freud consiste em reduzir uma diferença de função a uma diferença na magnitude das quantidades presentes de modo a poder conservar o postulado da identidade neuronal.

(16) Ibid., ESB, pp. 396-397, 411; SE, pp. 296, 310. "A descarga, como todas as outras, se efetua na direção da motilidade". Ibid., ESB, p. 414; SE, p. 311.

(17) Ibid., ESB, p. 419; SE, p. 315. A distinção quantidade externa/quantidade interna instala-se agora dentro do próprio aparelho da memória. 
Vemos, assim, que a distinção entre os dois sistemas neuronais é função da magnitude de quantidade a que eles estão submetidos. O aparelho neuronal proposto realiza, tanto estruturalmente como do ponto de vista funcional, o princípio da inércia e da constância naquilo que têm em comum: a suposição de que há por parte do organismo uma aversão ao aumento de quantidades. Enquanto estrutura, o aparelho procura manter as quantidades afastadas dos neurônios. Os estímulos externos, ao incidirem sobre as telas de redução, sofrem uma redução considerável: apenas uma pequena fração de Q atinge fi. Ela, por sua vez, é reduzida a uma quantidade intracelular no encontro com psi devido ao maior número de neurônios psi. Do ponto de vista funcional, os neurônios procuram, sempre que possível, descarregar a quantidade neuronal que possam conter. Caso não se consiga manter afastada a quantidade, há a produção do fenômeno da dor. Portanto, a tendência à fuga do estímulo doloroso nada mais é do que a tendência a evitar aumentos de quantidade no sistema nervoso. A irrupção dessas quantidades em psi tem como efeito a superação das barreiras de contato e, como conseqüência, o desaparecimento das diferenças de resistência entre elas, destruindo assim a capacidade de manter caminhos preferenciais pela igualação de todos os caminhos. ${ }^{18}$

Todos os processos descritos, até o momento, não envolvem consciência nem explicam como o aparelho transforma quantidade em qualidade. Freud acredita que há aqui três possibilidades para continuar desenvolvendo o seu modelo:

a) tratar os processos "fisiológico-psíquicos" como algo que existe independentemente da consciência e não são de nenhuma forma alterados pela sua presença ou ausência;

b) tratar a consciência como o lado subjetivo de todos os processos "fisiológico-mentais", portanto, como algo indispensável a esses processos; ${ }^{19}$

c) tratar a consciência como o lado subjetivo de uma parte dos processos físicos que se desenvolvem no sistema neuronal, cuja ausência acarretará a perda desses processos.

(18) Ibid., ESB, pp. 407-409; SE, pp. 305-307. A dor tem sempre uma origem externa. A recordação da dor não é dolorida, mas desprazerosa.

(19) Ibid., ESB, p. 414; SE, p. 311. A escolha da terceira alternativa introduzirá uma tensão conceitual muito forte dentro do "Projeto": na hipótese mais favorável significa a diminuição do papel organizador conferido à quantidade. 
A escolha recai sobre a terceira alternativa que, por sua vez, dá margem a trềs novas questôes: . $^{20}$
a) como a consciência é representada no sistema neuronal?
b) como se originam as qualidades?
c) onde se originam as qualidades?

Vamos respondê-las na ordem inversa, procurando simultaneamente exibir os argumentos de Freud ao adotar a terceira possibilidade e mostrar que essa opção coloca um sério problema para os pressupostos iniciais desse modelo.

Freud examina, um por um, os candidatos que poderiam ser responsáveis pela origem das qualidades:

a) mundo exterior - recusado porque nele há apenas "massas em movimento";

b) o sistema fi - recusado porque "a consciência se dá em níveis mais elevados";

c) o sistema psi - recusado porque nele "só há reprodução e recordação sem qualidade". ${ }^{21}$

A conseqüência dessa busca é supor um terceiro tipo de neurônio, os neurônios ômega, excitados no momento da percepção mas não da recordação. A excitabilidade daria lugar às diferentes qualidades, o que nos leva à segunda questão. Para resolvê-la, é preciso fazer algumas exigências sobre a estrutura dos neurônios ômega. Devem ser totalmente permeáveis de modo a poderem retornar ao estado inicial após a passagem da excitação. Mas, já que eles vão ser despertados após o sistema psi, como é possível conciliar essa permeabilidade completa com o fato das quantidades em psi serem muito pequenas? ${ }^{22}$

A solução está em recorrer a uma outra característica da quantidade: na transmissão neuronal haveria também um período, um fator temporal. Embora haja oposição à passagem de Q'n pelas barreiras de contato, não há qualquer obstáculo à transmissão de período. As diferenças entre eles são estabelecidas pelos órgãos dos

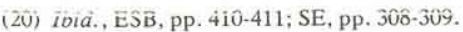

(21) Qualidade (logo, consciência) e recordação excluem-se mutuamente.

(22) Ibid., ESB, p. 412; SE, p. 310. A estratégia de Freud consiste em levar o leitor a acreditar que a dificuldade está em conciliar as hipóteses fundamentais do "Projeto" com a suposição de que há consciência. O problema reside na incapacidade de reduzir consciência à quantidade. 
sentidos que atuam como "crivos", deixam passar apenas estímulos dotados de certos períodos. ${ }^{23}$

Contudo, apenas um tipo de neurônio é capaz de decifrar o suposto fator temporal: o neurônio ômega. Ele transforma as qualidades distintas em sensações conscientes. Além da sua permeabilidade maior, de sua descarga se dar no sentido do sistema muscular, de serem carregados apenas a partir de psi, os neurônios ômega são leitores de períodos. Ora, é exatamente aqui que aparece um problema para os pressupostos iniciais. Freud pretendia descrever todos os processos psíquicos a partir unicamente dos conceitos de $\mathrm{Q}$ e de neurônio. A propriedade "ser leitor de período" por não ser redutível à quantidade transforma o neurônio ômega em um neurônio distinto de fi e psi. Logo, há uma contradição em relação aos dois postulados iniciais: os neurônios são estruturalmente idênticos e todas as diferenças são quantitativas. Para resolvê-la, é preciso considerar ômega, ou seja, a consciência como um conceito novo ao lado de neurônio e quantidade. A questão reside em saber como Freud vai encaminhar a relação entre esses três conceitos. Sem dúvida, ele tem consciência do problema uma vez que afirma ser impossível conferir um significado biológico a ômega semelhante ao dado a fi e psi; em outras palavras, ele não consegue justificar em termos da teoria da evolução a origem da consciência, embora, como vimos, acredite poder fazê-lo em relação à memória. ${ }^{24}$

O princípio da constância está presente em ômega sob a forma de prazer/desprazer. Prazer é uma percepção em ômega produzida pela diminuição das quantidades neuronais em psi, enquanto desprazer equivale a um aumento dessas quantidades. Logo, a relação entre ômega e psi é equivalente à que existe entre vasos comunicantes. Dentro de um certo intervalo quantitativo uma sensação consciente não é nem prazerosa nem desprazerosa. ${ }^{25}$

Podemos comentar agora esse esquema mais completo do funcionamento do sistema nervoso. Ele indica que os estímulos externos

(23) Ibid., ESB, p. 413; SE, p. 310. Notem como a suposição de uma característica temporal da quantidade parece satisfazer as condiçōes do "Projeto".

(24) Além de não conseguir explicar satisfatoriamente a consciência em termos quantitativos. Freud é igualmente incapaz de justificá-la em termos evolutivos, ou seja, pragmáticos: "não é possível imaginar qual foi o valor biológico primitivo dos neurônios ômega". Ibid., ESB, p. 414; SE, p. 311.

(25) Ibid., ESB, p. 415; SE, p. 312. 
ao incidirem sobre os órgãos do sentido, que funcionam simultaneamente como "crivos" e "telas de redução", se reduzem a certas magnitudes dotadas de determinados períodos. A magnitude é maior do que as barreiras de contato dos neurônios fi. A partir daí, parte da quantidade é "liberada" para o aparelho muscular, enquanto outra é "transferida" para psi do pallium. Para que este processo ocorra, é preciso que a quantidade que atinge o organismo esteja dentro de certos limites (muito baixa não será percebida; muito alta provocará o fenômeno da dor). ${ }^{26}$ Podemos precisar a observação prévia de que há uma redução quantitativa na passagem de fi para psi assinalando que um aumento quantitativo em fi leva a um aumento no número de neurônios envolvidos em psi. A partir desse sistema há uma transferência para ômega onde os períodos são interpretados, dando origem às qualidades. Em resumo, o contínuo fornecido pelos estímulos externos dá lugar no aparelho psíquico ao estabelecimento de descontinuidades, determinadas pela redução de quantidade e pela limitação dos períodos que apresentam. No caso dos estímulos endógenos, não existem essas "telas de redução" e eles atuam por somação. Acompanhemos o que ocorre, na primeira vez, em que esse processo se dá. Os estímulos endógenos vão incidir sobre psi do núcleo e, no início, não vão ser convertidos em estímulos psíquicos devido a sua pequena magnitude. Contudo, após uma certa quantidade, vão vencer as barreiras de contato de psi e levar a um acúmulo de Q'n, dando lugar ao que Freud chamou de "impulso motor do mecanismo psíquico" que se expressa mais tarde como "vontade o derivado das pulsões". ${ }^{27}$

Como observamos acima, há uma tendência a descarregar essa quantidade de excitação acumulada (função primária do sistema neuronal): ocorre uma liberação de quantidades para o aparelho motor, por exemplo, através de "gritos, inervação muscular". ${ }^{28}$ Todavia, a liberação não tem sucesso em impedir que o procesșo de somação prossiga no seu trabalho. Torna-se necessária a produção de uma ação específica, ou seja, que se produza uma modificação adequada nas condições do mundo externo. Somente ela pode interromper o processo de somação temporariamente. Ora, o organismo humano é incapaz de realizar por si só a ação específica; é necessário

(26) Ibid., ESB, p. 417; SE, p. 314.

(27) Ibid., ESB, p. 421; SE, p. 31\%. A vontade aparece então como produto da pulsão, como seu representante.

(28) Ibid., ESB, p. 421; SE, p. 317. 
que um outro a realize. Uma vez que se tenha produzido uma modificação adequada nas condições externas, há uma modificação adequada nas condições do mundo externo. Somente ela pode interromper temporariamente o processo de somação. Ora, o organismo humano é incapaz de realizar por si só a ação específica; é necessário que um outro a realize. Uma vez que se tenha produzido uma modificação nas condições externas, há uma interrupção no processo de somação, percebida por ômega como prazerosa. Portanto, o desaparecimento do desprazer é equivalente ao aparecimento do prazer. ${ }^{29}$

Examinemos as conseqüências dessa primeira e prototípica vivência de satisfação. Inicialmente havia uma grande catexia de neurônios do núcleo ligada a uma catexia de outros neurônios do pallium que registraram as alterações internas (chorar, inervação motora, etc.). Após a realização da ação específica por um outro, aparecem também outras catexias no pallium que se referem a esse outro e à descarga motora que interrompeu o processo de somação. Em outras palavras, estabeleceu-se no sistema psi um caminho de descarga, assinalado pela maior facilitação que essa rede de neurônios apresenta agora em relação a qualquer outra (função secundária do sistema neuronal). Freud considera que a presença necessária de um outro na produção da ação específica constitui a "fonte principal de todas as motivações morais". 30

O texto explica a maior facilitação, fixada na rede neuronal, pela vivência de satisfação, como resultado da "lei fundamental da associação por simultaneidade". Segundo ela, toda vez que um conjunto de neurônios é catexizado simultaneamente, é estabelecida de forma automática uma facilitação maior entre as suas barreiras de contato. $^{31}$ Como conseqüência dessa lei, na segunda vez em que ocorrer um processo de somação, aparecerá em psi uma tendência para catexizar os mesmos neurônios, ou seja, a seguir aquele mesmo caminho. Surge assim uma compulsão a repetir o mesmo trajeto, a

(29) Ibid., ESB, p. 422; SE, p. 318.

(30) Ibid., ESB, p. 422; SE, p. 318. Freud expressa aqui a oposição maior que se forma dentro do aparelho psíquico: a oposição entre a vontade (representante da pulsão) e a moral (produzida pela presença do outro na ação específica). Deve-se salientar que se o "Projeto" é a tentativa de explicitar uma teoria da pulsão, é completamente omisso em relação ao pólo da moral.

(31) Ibid., ESB, p. 423; SE, p. 319. A lei de associação faz com que o aparetho da memória retenha como sincrônico aquilo que foi diacrônico. Pois, evidentemente, os três pilares da cena prototípica - a necessidade, o outro e a satisfação não são produzidos simultaneamente, mas em sucessão. 
reencontrar o mesmo objeto que levou à interrupção do processo somatório; nos termos do texto, aparece uma "atração desiderativa primária". ${ }^{32}$ No entanto, como não há ainda a presença do objeto no mundo externo, também não há uma modificação adequada: ocorreu apenas uma hipercatexia da representação interna desse objeto, o que levou o organismo a repetir o mesmo circuito e a manter o desprazer, pois o processo de somação não foi interrompido. Houve, por conseguinte, uma alucinação visto que o modelo proposto distingue percepção de representação em termos puramente quantitativos. Portanto, é necessário que o organismo estabeleça critérios que lhe permitam diferenciar entre percepção e representação. Traduzindo a linguagem do modelo, o organismo deve evitar a catexização da representação do objeto desejado além de um certo ponto sob o risco de alucinar e ser frustrado na sua tentativa de se libertar dos estímulos endógenos.

Mas não são apenas as vivências de satisfação que exigem o estabelecimento desses critérios. A mesma necessidade aparece na vivência de dor, originada a partir de estímulos externos. Assinalamos anteriormente que a dor pode levar ao desaparecimento das diferenças de facilitação dentro do sistema psi, causadas por um grande aumento do nível de quantidades nesse sistema, e percebido em ômega como desprazer. Produz-se assim uma forte tendência à descarga que se vincula, através de uma facilitação, à representação do objeto que produziu a dor. Portanto, a catexização posterior dessa representação leva também ao aparecimento de um estado de desprazer. A questão está em saber como isso é possível uma vez que não há produção de quantidades externas pois, afinal de contas, trata-se apenas de uma representação, e representações são sempre menos intensas do que percepções. A solução consiste em supor que as representações de objetos hostis estão ligadas a "neurônios secretores", isto é, neurônios que, quando excitados, levam à liberação de quantidades no sistema psi, chamados de "neurônios-chave". 33 Estabeleceu-se em psi uma aversão a manter catexizada a representação do objeto hostil (uma compulsão a repetir), ou seja, há um

(32) Ibid., ESB, p. 427; SE, p. 322. A memória repete alucinatoriamente, na atração desiderativa, a primeira experiência de satisfação como se ela tivesse ocorrido em um vácuo temporal.

(33) Ibid., ESB, p.425; SE, p. 320. Fica sempre a impressão de que Freud possui um enorme baú com inúmeros tipos de neurônio, sempre à mão, para serem utilizados quando aparece uma dificuldade no desenvolvimento do texto. 
processo de defesa primária (recalque primário) que leva à imediata desgarga dessa representação. O que acrescenta uma nova complicação originada pelos estímulos externos e pela existência do próprio sistema psi. Quando essas experiências de dor foram produzidas, elas terminaram através de uma defesa reflexa. $\mathrm{O}$ aparecimento de um outro objeto no lugar do hostil adquiriu a possibilidade de sinalizar que a vivência dolorosa havia terminado. ${ }^{34}$ Portanto, também deve existir em psi um critério que permita evitar a catexia desses neurônios que representam objetos hostis. Assim se evita a produção de desprazer em ômega e a tentativa de catexizar representações que indiquem o final da experiência dolorosa quando ela ocorreu pela primeira vez. Em outras palavras, se é necessário manter caminhos preferenciais, é também imperativo conter a alucinação. Se não existisse memória, os estímulos dolorosos não colocariam nenhum obstáculo ao princípio da inércia. A existência de psi leva a representações de objetos. hostis e à necesidade de se passar para o princípio da constância.

Temos, dessa forma, dois tipos de circuito por parte do organismo: os de satisfação (originários de um processo interno de somação) e os de dor (originados a partir de um impacto produzido por estímulos externos). Ambos levam ao desprazer se o sistema psi não aprender a tomar certas precauções. $O$ seu aprendizado é feito através de experiência biológicas que levam o organismo a evitar a repetição dessas vivências fora de certas condições. Como resuitado, surge um novo sistema dentro de psi, o ego, que visa evitar que tanto a representação do objeto desejado como a do objeto hostil sejam catexizadas sem que esses objetos existam no mundo exterior. ${ }^{35}$ Sua principal função é a de inibir os processos primários. O ego forma-se a partir do acúmulo de Q'n em psi do núcleo, causado pelos estímulos endógenos. Ele define-se como a "totalidade de catexias psi existentes em um dado momento". ${ }^{36}$ Vai assegurar os caminhos preferenciais através de um processo chamado inibição. Este consiste em evitar que, em situações desiderativas, a representação do objeto procurado seja catexizada, além de um certo limite, enquanto

(34) Ibid., ESB, p. 427; SE, p. 322. Trata-se de uma tentativa de assimilar um tipo de vivência ao outro: em ambos os casos haveria uma tendência para hipercatexizar uma representação. A alucinação produz-se quando ômega toma uma representação de psi como se fosse uma sensação produzida por fi.

(35) Ibid., ESB, p. 428; SE, pp. 322-323.

(36) Ibid., ESB, p. 428; SE, p. 323. 
ele não estiver no mundo exterior, e em impedir a catexização do objeto hostil. ${ }^{37} \mathrm{Em}$ ambos os casos haveria desprazer. O processo de inibição é alcançado a partir da contínua observação realizada pelos neurônios perceptuais. ${ }^{38}$

Ora, para que o ego cumpra a sua finalidade, é necessário que ele diferencie claramente entre percepção e representação. Essa diferença é estabelecida mediante a produção de um sinal de realidade dado por ômega. Toda vez que ocorrer uma falha nesse critério, haverá a produção de processos primários dentro do ego. Por exemplo, se o critério funciona, a atenção dirigida à percepção de um objeto hostil, levará à inibição da representação desse objeto, através de catexias laterais, de modo que a defesa será de magnitude normal; caso contrário ocorrerá, de novo, um recalque primário. ${ }^{39}$ Dessa forma, os processos secundários são "versões atenuadas de processos primários" através da "utilização correta de sinais de realidade". ${ }^{40}$ Em outras palavras, eles são a garantia de que não haverá produção de grandes quantidades em psi, logo, de desprazer em ômega.

Descreveremos inicialmente os processos secundários que se dão no ego para, no final do texto, explorar as conseqüências do aparecimento de processos primários nesse sistema, ou seja, os sonhos e as neuroses.

Todos os processos de pensamento que se estabelecem no ego (processos secundários) têm como finalidade explícita estabelecer um estado de identidade entre uma representação e uma percepção. ${ }^{41}$ Freud distingue inicialmente duas formas de pensamento: reprodutivo e cognitivo. Uma das diferenças que elas apresentam entre si está no fato de, ao final do processo de identificação, ocorrer ou não uma descarga nessa representação. Em caso afirmativo, o

(37) Ibid., ESB, pp. 428-429; SE, pp. 323-324. Seria muito interessante relacionar o ego com a moral.

(38) Em outras palavras, a função de atenção, a catexia contínua dos neurônios perceptuais, é fundamental para a realização da função de inibição. $O$ organismo apresenta uma tenđência contínua para alucinar, isto é, para preencher automaticamente o desejo.

(39) Ibid., ESB, pp. 432-433; SE, pp. 326-327.

(40) Ibid., ESB, p. 433; SE, p. 327. O funcionamento do ego parece depender muito mais de ômega do que da ação do outro; parece depender muito mais de fatores biológicos do que culturais.

(41) Ibid., ESB, p. 439; SE, p. 332. Em outras palavras, todo processo de pensamento é dirigido no sentido de repetir as velhas experiências de satisfação. 
pensamento é descrito como reprodutivo; caso contrário, ele é cognitivo. Mas há uma outra diferença entre eles que merece ser estudada em profundidade. Para tanto, examinemos as três situações que podem existir entre uma representação e uma percepção: a de identidade, a de semelhança e a de diferença. ${ }^{42}$

No caso da identidade, há uma coincidência entre a representação do objeto desejado e a percepção desse objeto. Ocorre, portanto, uma sobreposiçāo de duas catexias, onde a descarga produzida em ômega é um sinal de realidade para que haja descarga em psi. Logo, não há necessidade de qualquer atividade cognitiva; nos termos do texto, trata-se de uma situação que "não é aproveitável biologicamente". ${ }^{43}$

O caso da semelhança é muito mais importante do ponto de vista biológico porque vai dar origem à atividade do pensamento. Freud afirma que a representação do objeto não é dada por um único neurônio, mas por um complexo onde há uma parte fixa, denominada a coisa ("Das Ding"), e uma variável, chamada atributo, predicado, atividade da coisa. A parte fixa pertence a psi do núcleo enquanto os predicados se encontram no pallium. ${ }^{44}$

Podemos observar que a representação de um objeto não é uma simples imagem do objeto, mas um complexo onde intervém uma parte do próprio sujeito, pois, como já foi dito, todas as representações de origem externa encontram-se no pallium, o que significa que a parte fixa é de responsabilidade do sujeito. Por conseguinte, o fundamento da identidade está na pulsão e no outro.

Voltando ao caso da semelhança, constatamos que, quando ela ocorre, o organismo aprendeu biologicamente que não deve iniciar a descarga enquanto não se estabelecer uma conexão entre dois predicados. Por exemplo, seja (A-B) a representação desejada, e (A-C) a percepção presente. Nesse caso existe um dispositivo chamado "julgamento" que procurará encontrar uma conexão entre B e C. Dois fatores orientam o julgamento: ${ }^{45}$

a) a representação do objeto desejado mantém-se catexizada durante todo o tempo em que se dá a procura, isto é, B conserva

(42) Ibid., ESB, pp. 433-439; SE, pp. 327-332.

(43) Ibid., ESB, p. 433; SE, p. 327 . O critério é sempre o da utilidade em termos da sobrevivência do organismo.

(44) Ibid., ESB, p. 434; SE, p. 328. Portanto, não pode existir nunca consciência da coisa uma vez que não há consciência da parte nuclear de psi.

(45) Ibid., ESB, p. 436; SE, pp. 329-330. 
uma catexia constante, o que cria um grau de facilitação maior para todas as conexões possíveis que B possa manter com outros neurônios;

b) se, no percurso a partir de $\mathrm{C}$, a quantidade chegar a uma representação dolorosa, haverá uma série de catexias laterais, estabelecidas durante o desenvolvimento do ego, que conduzirão a quantidade em uma outra direção.

Assim que for estabelecida a identidade, ocorrerá ou não uma descarga de B, dependendo da atividade cognitiva envolvida. Mas, mesmo no caso de pensamento cognitivo sempre se visa um fim prático: decidir rapidamente se o objeto que se encontra diante do organismo é o mesmo que está sendo procurado, ou seja, desejado.

No caso da diferença não existe nenhuma coincidência entre representação e percepção. Aqui se abrem duas possibilidades: ${ }^{46}$

a) a percepção não é nova e cai-se no caso anterior porque ela leva a uma representção sobre a qual se pode exercer um julgamento;

b) não há nenhuma coincidência com elementos já presentes em psi, e pode ocorrer tanto uma pesquisa a partir das representações que foram motivadas por essa percepção como dos próprios elementos introduzidos por essa percepção, sem que em nenhuma das atividades haja um objetivo, ou seja, a procura é "dirigida pelas diferenças e não pelas semelhanças". 47

Antes da existência do julgamento secundário, havia o primário, ou seja, antes do surgimento do ego havia, por parte do sistema neuronal, uma tendência para estabelecer coincidências parciais entre catexias de objeto desejado ou hostil e catexias produzidas em ômega pela percepção; contudo, sem produzir qualquer alteração nas suas relações. Era um processo puramente associativo baseado na lei de simultaneidade. ${ }^{48} \mathrm{O}$ julgamento secundário surgiu como uma atenuação do primário mas sem alterar radicalmente esses percursos. Ele é uma garantia de que os percursos serão efetivamente percorridos uma vez que leva em conta a realidade. A sua condição de possibilidade está dada pela constituição do ego, isto é, de neurônios fortemente catexizados, ligados entre si de modo a di-

(46) Ibid., ESB, pp. 437-438; SE, p. 331.

(47) Ibid., ESB, pp. 437-438; SE, p. 331.

(48) Ibid., ESB, pp. 440-441; SE, pp. 333-334. 
ficultar o deslocamento de quantidades e a poder estabelecer inibições quando for necessário.

Freud exemplifica os processos secundários com um caso que vai nos levar a examinar um pouco melhor o enunciado de que a presença do outro na produção de uma ação específica constitui a "fonte principal de todas as motivações morais".

Suponhamos, seguindo o texto, que o primeiro objeto que se apresente à percepção seja semelhante ao próprio sujeito. Neste caso, ocorre uma tripla determinação em relação a esse objeto. Ele é simultaneamente:

a) o primeiro objeto de prazer;

b) o primerio objeto hostil;

c) a única força auxiliar do sujeito. ${ }^{49}$

Esta simultaneidade de funções leva Freud a afirmar: é nos seus semelhantes que o ser humano aprende pela primeira vez a se reconhecer. ${ }^{50} \mathrm{~A}$ última determinação possibilita as duas primeiras e introduz uma grande complexidade em psi. Se esse outro é simultaneamente objeto desejado e hostil, como é possível manter a crença de que o circuito do prazer é diferente do da recordação da dor? A única saída que se pode sugerir é a de conceber que duas representações do mesmo objeto são semelhantes mas não idênticas. Em outras palavras, trata-se da mesma "coisa" mas de "predicados" diferentes.

Segundo Freud, os complexos perceptivos que decorrem da presença de um outro podem ser divididos em duas partes: ${ }^{51}$

a) algo constante - a coisa;

b) algo que pode ser compreendido pela memória do sujeito quando ele compara essas representações com informações que se originam do próprio corpo.

Logo, existe uma parte do complexo neuronal que permite estabelecer uma semelhança mas que não pode ser reconhecida pelo sujeito. A razão disso está no fato de Freud considerar as coisas

(49) Ibid., ESB, p. 438; SE, p. 331. Nos termos do "Projeto", como veremos, essa tricotomia expressa que o outro é ao mesmo tempo, por ser a única força auxiliar do sujeito, o objeto da pulsão e o objeto formador da moral. Essa simultaneidade mostra como, em Freud, o desejo e a lei moral são instituídos por um único golpe, de uma só vez.

(50) Ibid., ESB, p. 438; SE, p. 331.

(51) Ibid., ESB, p. 438; SE. p. 331. 
como "resíduos que foram subtraídos ao julgamento. ${ }^{52} \mathrm{O}$ que parece indicar que a coisa é realmente uma espécie de coisa em si. Por outro lado, a parte variável do complexo, os predicados da coisa, possibilita ao sujeito reconhecer os próprios movimentos corporais a partir dos movimentos do outro. Nisto reside a outra diferença entre pensamento reprodutivo e cognitivo. No primeiro caso, trata-se de uma catexia de representação do objeto desejado - uma catexia psíquica - enquanto que no segundo, são catexias do próprio corpo, isto é, representações corporais. ${ }^{53}$

Quando se acrescenta, a essa última forma de pensamento, um sinal de realidade proveniente de ômega, tem-se um "julgamento de realidade, uma crença que é o objetivo de toda essa atividade". ${ }^{54}$ Pois, como já observamos, a introdução do ego, como conseqüência das experiências biológicas, é a garantia da existência de objetos no mundo exterior.

Estudamos acima que essa garantia é fornecida através da produção de um sinal de realidade por parte de ômega. Existe, portanto, um mecanismo no ego que o leva a seguir as representações formadas em psi do pallium e a influir sobre elas a partir das descargas dos neurônios ômega. O mecanismo, chamado de atenção psíquica, vai procurar catexizar em psi os neurônios equivalentes aos que estão presentes em ômega; onde, por hipótese, se forma a consciência das qualidades. Ele surge para evitar experiências de desprazer, ou seja, é o resultado de repetidas experiências biológicas que acabaram por estabelecê-lo. Por exemplo, o estado de anseio que dará lugar posteriormente aos estados desiderativos (pensamento reprodutivo) e de expectativa (pensamento cognitivo), contém toda a justificativa para o surgimento dessas modalidades de pensamento. Pois, como já foi assinalado, trata-se de encontrar uma identidade entre uma representação já constituída e uma percepção de modo a poder percorrer de novo o caminho que deu fim ao processo de somação. Por conseguinte, o mecanismo de atenção consiste em

(52) Ibid., ESB, p. 441; SE, p. 334.

(53) Ibid., ESB, pp. 439-440; SE, p. 332. A teoria da sedução infantil, como será explicitado adiante, baseada numa cena sexual ocorrida na infância, supõe que a sexualidade envolvida é genital e inexiste na infância. Uma vez que a criança não consegue reconhecer no próprio corpo o corpo do outro, a cena não pode ser compreendida pela atividade do pensamento. Será preciso esperar a puberdade, o aparecimento das características sexuais secundárias, para que se abra a possibilidade para esse reconhecimento.

(54) Ibid., ESB, p. 440; SE, p. 333. 
evitar que a representação do objeto desejado seja catexizada antes que surja uma descarga proveniente de ômega a partir dos neurônios correspondentes. Se não houver nenhum acordo entre o complexo perceptivo em ômega e o complexo representativo no ego, o mecanismo de atenção passa a pesquisar o sistema psi do pallium a fim de estabelecer um estado de identidade. O que justifica a definição do ego como a totalidade de catexias em psi, onde uma parte é fixa (o núcleo) e a outra variável (o pallium). ${ }^{55}$

Freud procura descrever como se formou o mecanismo de atenção. Ele supõe que, quando ocorreu pela primeira vez o término do estado de anseio, a representação do objeto que a terminou era dotada de uma catexia muito pequena, dada pela produção de um sinal de realidade por parte de ômega. Contudo, numa situação posterior de desejo já existe uma catexia prévia dessa representação no pallium (lei da associação por simultaneidade). Com a constituição do ego, essa catexia serve para orientar o mecanismo de atenção, isto é, ela vai evitar que a representação envolvida se torne hipercatexizada antes que ocorra um sinal de descarga vindo de ômega a partir do neurônio correspondente. Qualquer coisa que ocorra que não siga exatamente esses passos irá produzir desprazer: é isso que orienta a atenção para a catexia de certos neurônios e não para de outros. A quantidade maior presente nesses neurônios, ou o que é equivalente, sua maior facilitação, serve como indicador das vias preferenciais, permitindo explicar mecanicamente a atenção.

Quando a excitação produzida pelo estímulo externo é muito pequena, ela não mobiliza no ego o mecanismo de atenção. Por conseguinte, a quantidade produzida em psi segue o caminho das melhores facilitações de maneira puramente associativa até se deter em algum neurônio. Ocorreu um fracasso no mecanismo de atenção, mas não houve quaisquer conseqüências patológicas porque a quantidade envolvida era muito pequena. ${ }^{56}$ No final do texto, examinaremos o que ocorre quando as quantidades são maiores e a atenção falha.

Caso não haja fracasso nesse mecanismo, podem surgir várias formas de pensamento cognitivo. Por exemplo, o "pensamento meramente observador" onde o "investigador tendo realizado uma percepção se interroga: 'O que significa isto?' 'Para onde isto nos con-

(55) Ibid., ESB, pp. 473-5; SE, pp. 360-361.

(56) Ibid., ESB, pp. 476-477; SE, p. 363. 
duz?" ", ${ }^{57}$ Neste caso, a atenção leva a uma substituição: no lugar da representação eliciada pela descarga em ômega surgirão outras representações associadas com a representação inicial. Como resultado do indivíduo ter realizado este pensamento, ele criou uma maior facilitação entre as representações; ou, nos termos do texto, ele procurou conhecer os caminhos que partem do sistema ômega na sua maior extensão possível de modo a "esgotar o conhecimento do objeto perceptivo". ${ }^{58}$ Logo, o conhecimento do objeto é fruto de todas as ligações existentes entre a coisa e os seus predicados, enunciado que explicitaremos mais adiante. No entanto, pode-se perguntar: como o ego sabe que representações deve catexizar? No caso de um estado desejante, há um sinal de realidade dado por ômega. Quais são os sinais deixados pelo pensamento?

Freud acredita que, do mesmo modo que no primeiro caso, também aqui deve existir uma descarga. Portanto, é suficiente supor que no processo de pensamento há neurônios motores que, uma vez catexizados, descarregam uma quantidade, dando origem a um sinal de realidade. Todavia, nem todas as descargas são motoras. Para contornar essa objeção, Freud recorre a um outro tipo de neurônio que se relaciona intimamente com neurônios motores: os neurônios utilizados pelas representações motoras da fala. ${ }^{59}$

Freud define associações verbais como uma conexão entre neurônios psi do pallium e representações da fala. ${ }^{60} \mathrm{O}$ percurso a ser seguido pelo pensamento é o da representação do objeto para a representação do nome e daí para a representação motora do nome. O reconhecimento do pensamento consciente observador é possível devido a essa associação. Em suma, quando ocorre essa forma de pensamento, há uma pré-catexia das representações da fala de modo a conduzir as quantidades em psi para aquelas representações percorridas inicialmente. Como conseqüência, a descarga motora de representações da fala é simultaneamente sinal de qualidade e sinal de que a representação é consciente. Logo, há uma segunda contribuição por parte das associações verbais: além de fornecerem sinais de realidade para os processos de pensamento, tornam possível a sua recordação. ${ }^{61}$

(57) Ibid., ESB, p. 477; SE, p. 363.

(58) Ibid., ESB, p. 478; SE, p. 364.

(59) Ibid., ESB, pp. 478-479; SE, p. 365.

(60) Ibid., ESB, pp. 478-479; SE, p. 365.

(61) Ibid., ESB, p. 479; SE, p. 365. 
Contudo, permanece uma questão: como diferenciar uma representação eliciada pela percepção de uma suscitada pelo pensamento? A resposta consiste em localizar a origem da descarga, isto é, a origem da quantidade que catexizou a representação. Se ela provém de ômega, a representação é perceptual; se ela decorre de uma descarga de uma representação da fala, então é cogitativa. ${ }^{62}$

Mas qual é a origem dessas associações verbais? Segundo Freud, sua pré-história se inicia com os primeiros sons emitidos pelo ser vivo. Estudamos o fato de que, na primeira vez, em que se produziu um estado de anseio, o organismo utilizou a inervação do aparelho da fonação (gritos, sons inarticulados) como uma forma de diminuir as quantidades produzidas pelos estímulos endógenos. Dessa forma, a inervação antecede a ação específica. No entanto, é insatisfatória por não provocar uma interrupção nos processos de somação. Mas, a partir da realização da ação específica por um outro, passa a desempenhar uma função secundária: serve para atrair a atenção desse outro, geralmente, ao mesmo tempo, aquele que realiza a ação é o primeiro objeto de desejo. ${ }^{63}$ Em outras palavras, os sons passam a ter uma função de comunicação além de serem incluídos entre o circuito dos neurônios que formam as vias preferenciais.

Resumindo, podemos ver que a "associação verbal" (associação entre sons emitidos pelo organismo e certos estados de anseio), no início, faz parte de um processo interno de diminuição da quantidade. A necessidade da presença de um outro transforma esse processo de descarga ( $a$ inervação do aparelho fonador) também em um sinal para que o outro perceba os processos internos que estão ocorrendo na criança. Contudo, isto não significa que se tenha constituído na criança uma função significante. Para examinar a sua gênese, estudemos a relação que se estabelece entre compreensão e expressão verbal.

A compreensão é definida como o processo mediante o qual o ego conhece através da sua própria experiência os atributos, as ati-

(62) Ibid., ESB, p. 480; SE, p. 366.

(63) Ibid., ESB, p. 480; SE, p. 366. Portanto, a fala também faz parte do circuito da ação específica; em outras palavras, ela está presente mesmo quando a criança não é ainda capaz, ela própria, de falar. O que aponta na direção de se conferir à linguagem um papel constitutivo na formação do aparelho psíquico. 
vidades da coisa. ${ }^{64}$ Sabemos que há duas vivências fundamentais para o ego: a vivência de dor e a vivência de satisfação.

No caso da dor, a relação se estabelece entre a representação do objeto hostil e a "notícia" do próprio grito, ou seja, entre representação e descarga parcial de quantidades através da inervação do aparelho fonador. A descarga passa a ser um sinal de qualidade que, como vimos, desempenha um papel duplo:

a) indica que o processo foi real, que a experiência de dor realmente ocorreu;

b) possibilita a recordação da experiência, o que vai mobilizar por parte do ego o mecanismo de atenção, de modo a evitar que a catexização de representações produza desprazer em ômega.

Freud expressa o resultado do processo acima nas seguintes palavras: "são exatamente essas experiências que vão formar a primeira classe de recordações conscientes". Mais adiante, "a partir daí, basta um curto passo para chegar à invenção da fala". ${ }^{65}$

A única maneira de se entender porque basta tão pouco para se inventar a fala está em notar que existe um pressuposto implícito na teoria do Projeto: a fala já foi "inventada", ela está dada a priori. Quando estudamos o processo de julgamento, vimos que as relações que ele procura estabelecer fundamentam-se na crença de que é possível decidir se há uma identidade entre a coisa dada pela representação e a que é dada pela percepção. Também afirmamos que o problema reside em determinar qual a natureza da coisa. Cabem, pelo menos, duas hipóteses: a coisa é de natureza biológica, ou seja, o que permite estabelecer relações entre impressões psíquicas reside na possibilidade biológica de transferir "conhecimento" adquirido através de um tipo de impressão para outro; ou ela é uma pura referência. Acreditamos que o texto vai progressivamente na direção da segunda hipótese, suspeita que será maior quando examinarmos, mais adiante, em novo contexto, as relações estabelecidas entre percepção e pensamento.

No caso da experiência de satisfação existirão objetos em cujo complexo perceptivo aparece também um som. Devido à tendência imitativa do aparelho psíquico, dada pela lei de associação por simultaneidade, se estabelece uma relação entre representação do objeto e representação auditiva, o que vai possibilitar que o sujeito

(64) Ibid., ESB, p. 481; SE, p. 366.

(65) Ibid., ESB, p. 481; SE, p. 367. 
tome consciência desse objeto. A partir daí, segundo o texto, para chegar à fala "basta juntar associativamente às percepções os sons deliberadamente produzidos, para que as recordações despertadas ao atender aos sinais de descarga tonal se tornem conscientes, como as percepções, e possam ser catexizadas a partir de psi". ${ }^{66}$

Podemos constatar que a expressão "deliberadamente produzidas" se refere a esse outro que, diante da criança, produz certos sons, mais tarde reconhecidos por se terem juntado a representações do objeto. Esse reconhecimento não se limita ao próprio som (a fala do sujeito), mas permite tomar consciência do objeto e da relação que ele guarda com o próprio sujeito, uma vez que o som passou a fazer parte da "representação do objeto". Pode-se, portanto, afirmar que, no pensamento cognitivo, o mecanismo de atenção está dirigido, desde o início, para os sinais de descarga cognitiva, ou seja, para os sinais da fala. ${ }^{67}$

Mas não haveria um gasto excessivo em termos quantitativos durante a realização desse tipo de pensamento devido à hipercatexia dos neurônios motores da fala?

Na realidade, não. O gasto é muito pequeno porque "não se fala quando se pensa" e "não se movimenta quando se pensa em movimento". ${ }^{68}$ Por conseguinte, as quantidades envolvidas são pequenas. $\mathrm{O}$ que aparentemente leva a uma aporia: como conciliar as hipercatexias da percepção e da representação com pequenos deslocamentos de quantidade? A resposta está na própria constituição do ego que, como vimos, consiste precisamente em manter um alto nível de catexia entre neurônios que se encontram ligados entre si. Logo, o mecanismo de atenção consiste em catexizar um neurônio perceptivo (a parte variável do ego em psi do pallium) com a mesma catexia que apresenta a parte fixa (psi do núcleo). Portanto, o estado de "energia ligada" permite explicar os processos secundários em termos sincrônicos, isto é, em termos de uma explicação mecânica, embora Freud acredite poder apenas tecer algumas considerações sobre o assunto sem ter condições de aprofundar mais a questão.

(66) Ibid., ESB, p. 481; SE, p. 367.

(67) Ibid., ESB, p. 481; SE, p. 367. A presença necessária do outro na aquisição da fala faz com que a mesma forneça a matéria-prima para a elaboração dos sintomas. A suposição de que o outro estabeleceria as relações profundas entre os termos da fala, isto é, a sua condição de inteligibilidade, não parece despropositada.

(68) Ibid., ESB, p. 482; SE, p. 367.

(69) Ibid., ESB, pp. 482-483; SE, pp. 368-369. 
As explicações biológicas, ao contrário, estão sempre à mão para dar conta da origem desses processos. Vimos como surge o ego, um estado de "energia ligada" entre neurônios, e constatamos que a essência de sua gênese reside em erguer barreiras contra a catexização do objeto desiderativo na ausência de um sinal de realidade e contra a descarga motora da representação do objeto hostil. A criação dessas barreiras (o processo de inibição) foi justificada afirmando-se que qualquer outro processo que não fosse esse levaria ao desprazer. Portanto, a passagem da primeira regra biológica, a defesa primária, que consiste na descarga imediata de quantidades neuronais, para a segunda regra biológica, o mecanismo de atenção, é concomitante com a transição do princípio de inércia para o da constância e dos processos primários para os secundários. A segunda regra biológica ensina que, quando aparece um sinal de realidade, a catexia perceptiva que existe em psi do pallium deve ser simultaneamente hipercatexizada. ${ }^{70}$

Pode-se questionar se os processos secundários ocorrem somente quando já existe a fala. A resposta é negativa. O que sugere uma nova questão: qual a utilidade dos sinais de qualidade (sinais da fala) se o ego pode produzir o mesmo curso associativo na sua ausência? ${ }^{71}$

Antes de responder, Freud faz algumas considerações sobre a relação entre sinais de realidade e os da fala. Inicialmente, é preciso levar em conta que os sinais da fala também são sinais da realidade exterior. Além disso, quando a atenção não os considera, a produção de desprazer é muito menor em comparação com a que surge quando se ignora o mundo externo. No entanto, Freud considera que "ambos os casos são, no fundo, um e o mesmo caso". 72

Podemos retornar, agora, à questão que parece ser central no "Projeto": qual é a natureza da coisa? A última afirmação de Freud, ao igualar o desprazer que decorre ao não se levar em conta o mundo externo (sinal de realidade) e o que decorre ao não se considerar os sinais da fala (sinal de qualidade), abre, pelo menos, duas possibi-

(70) Ibid., ESB, pp. 486-487; SE, p. 371.

(7i) ibia., ESB, p. 488; SE; p. 372. Ou seja, para Freud existé pensamento desvinculado da linguagem. Esta é apenas condição para se ter acesso ao conteúdo pensado.

(72) Ibid., ESB, p. 489; SE, p. 373. Je o pensamento pode existir independentemente, não é menos verdade que a linguager- acaba por ter um papel constitutivo em relação ao aparelho psíquico. 
lidades: ou os dois sinais são de natureza biológica ou são de natureza semântica. A primeira interpretação levaria a ver a coisa como biológica, o que coloca, de imediato, o problema de saber como o ego estabelece as identidades e semelhanças, como ele apresenta um grau tão grande de acerto em relação às representações que deve catexizar. A segunda interpretação parece ser mais defensável e implica aceitar que a natureza da coisa consiste em ser uma pura "referência", ou seja, "as coisas são resíduos que se furtaram ao julgamento", isto é, não foram nunca predicados de nenhuma outra coisa. $^{73}$

Segundo Freud, a utilidade dos sinais de qualidade está em intensificar certas catexias no curso associativo, assegurando. dessa forma, a presença do mecanismo de atenção; o qual, por sua vez, assegura a imparcialidade do curso associativo. Em outras palavras, os sinais da fala são sempre úteis porque orientam o mecanismo de atenção e assim defendem o ego de catexias desiderativas. Tal consequiência leva Freud a afirmar algo que ele já havia dito, com outras palavras, na "Comunicação Preliminar": "o pensamento que é acompanhado pela catexização de sinais de realidade cognitiva ou indicações da fala representa a forma mais elevada e segura do processo de pensamento cognitivo". ${ }^{74}$

As considerações acima indicam que existem formas de pensamento que não são acompanhadas de sinais da fala, nas quais o ego assume, automaticamente, o curso associativo de suas catexias de acordo com a regra biológica da atenção. Elas são consideradas como sendo freqüentes e na sua maior parte como sem consciência, embora, ocasionalmente, possam apresentar consciência em alguns pontos. Logo, consciência e processo secundário não estão sempre juntos; aliás, a consciência pode se ligar a processos primários, como veremos ao final do texto. ${ }^{75}$ Contudo, antes de passar a este ponto,

(73) A coisa é um residuo que escapa à parte predicativa do juizo, embora permaneça enquanto sua pura referência.

(74) Ibid., ESB, p. 490; SE, p. 374.

(75) A consciência aparece com as mesmas características do sistema perceptual e não desempenha qualquer papel organizador no aparelho psíquico: "Além disso, é interessante que, nos sonhos, a consciência forneça qualidade com a mesma facilidade que na vida desperta. Isso demonstra que a consciência não se restringe ao ego, podendo agregar a qualquer processo psi. Isso nos adverte, também, contra uma possivel identificação dos processos primários com os processos inconscientes. Eis aqui dois conselhos preciosos para o futuro!". Ibid., ESB, p. 449; SE, p. 340. 
examinemos os fatores que podem perturbar o curso do pensamento acompanhado de consciência.

Qualquer catexia de outro neurônio que concorra com a catexia de um sinal da fala pode alterar o curso associativo e assim tornálo não consciente. Outra possibilidade reside na emergência de grandes quantidades que levam a uma aceleração muito grande no processo de pensamento, dando lugar a expressões, por parte dos sujeitos, do seguinte tipo: "algo me ocorreu com tal rapidez que não me dei conta". ${ }^{76}$ Portanto, a garantia da presença de sinais de fala nos processos cogitativos reside na passagem de pequenas quantidades, isto é. na existência daquilo que poderíamos chamar de um ego "bem estruturado", embora seja verdadeiro que o "despertar dos sinais de fala não é o único caminho para a conscientização". 77

Freud estuda outro tipo de relação entre pensamento e consciência: o pensamento recordativo. Ele é uma condição necessária para todo exame realizado pelo pensamento crítico (pensamento que surge quando, após a ocorrência do pensamento reprodutivo, o resultado é desprazer). Ele persegue o curso realizado pelo processo cognitivo na contramão, recorrendo com grande freqüência aos signos de qualidade. Em outras palavras, o pensamento recordativo vai permitindo ao sujeito que ele tome consciência das etapas percorridas durante o pensamento cognitivo, que não eram conscientes, através do uso de sinais de qualidade. ${ }^{78}$

Mas, como é possível que o pensamento prático conduza ao desprazer? A resposta consiste em supor que a representação que ele catexizou se refira a uma percepção de um objeto hostil, ou seja, a uma experiência de dor. $\mathrm{O}$ senso-comum acredita que tais representações aparentemente perdem essa capacidade em função do tempo. No entanto, Freud nos ensina que a perda não se deve ao tempo; o tempo é apenas uma dimensão do processo. A verdadeira razão

(76) Ibid., ESB, p. 491; SE, pp. 374-375.

(77) Ibid., ESB, p. 492: SE, p. 375.

(78) Ibid., ESB, p. 497; SE, pp. 379-380. Isto é, o pensamento recordativo envolve uma espécie de regressão (a quantidade vai no sentido da representação para a representação-percepção) dentro do sistema psi. Contudo, ela não envolve grandes quantidades, não há o risco de um processo alucinatório. Se não existisse, por outro lado, o sintoma neurótico, seria possivel, através do pensamento recordativo, reconstituir o circuito de representações percorrido pelo sujeito. Contudo, a essência da formação de sintomas reside precisamente na exclusão de certas representações do ego. 
está no trabalho realizado pelo ego. Ele vincula a si a representação do objeto hostil aumentando a sua catexia mas, ao mesmo tempo, impedindo que haja uma descarga (defesa primária) pelo aumento do grau de resistência da representação. Surge assim uma defesa cogitativa primária que consiste em colocar em funcionamento o mecanismo de atenção que desvia a catexia toda vez que estiver iminente a catexização da representação do objeto hostil. ${ }^{79}$

Além do desprazer, o pensamento também pode conduzir à contradição. O que leva a duas novas questões, intimamente interligadas: em que consiste o erro? Como é possível cometê-lo? ${ }^{80}$

Sabemos que o objetivo geral de toda forma de pensamento é elaborar caminhos que levem dos atributos da coisa até o complexo coisa, independente de percepções contingentes que estejam presentes diante do organismo. O pensamento possibilita a premeditação por parte do aparelho psíquico: trata-se sempre de reconhecer os objetos que se encontram no mundo exterior. Ele trabalha pela substituição das facilitações associativas (processos primários) por facilitações cogitativas (processos secundários), sem que isso acarrete uma modificação substancial nos caminhos iniciais, sob pena de falsificar a realidade. Devemos ter presente que a introdução dos processos secundários se dá para garantir a realização dos circuitos primários. No entanto, mesmo aqui é possível errar, ou seja, não estabelecer corretamente a relação de identidade entre percepção e representação. As fontes de engano podem estar no processo de julgamento, na adoção de vias de pensamento, ou, ainda, no próprio pensamento. ${ }^{81}$

No processo de julgamento, elas podem decorrer da omissão de alguns elementos na relação entre o complexo-coisa e os complexos-movimento. Isto pode ocorrer por não se levar em conta todos os neurônios que formam o complexo-coisa (chamado de "equívoco de julgamento por defeito das premissas") ou por não se perceber completamente os objetos por "se acharem fora do campo dos sentidos" ("equívocos por ignorância, inescapáveis a todo ser humano"),

(79) Ibid., ESB, pp. 500-501; SE, pp. 382-383. Portanto, é através da defesa cogitativa primária que se estabelecem as diferenças entre as representações e surge a noção de tempo, ou seja, a possibilidade de se poder afirmar que uma representação é mais antiga do que outra.

(80) Ibid., ESB, p. 501; SE, p. 383.

(81) Ibid., ESB, pp. 502-505; SE, pp. 384-386. As consideraçôes sobre o erro são importantes na medida em que permitem precísar o conceito de sintoma. 
ou ainda por distração do ego em relação às percepções ("equívocos por atenção insuficiente"). Nas vias de pensamento, o erro pode surgir da adoção de um caminho inadequado, o que acaba por produzir um "movimento antieconômico". O processo de pensamento cognitivo, ao pesquisar todas as vias possíveis, acaba por adotar um caminho que se revela inadequado exatamente pelo seu custo em termos energéticos; havia formas mais curtas de estabelecer a identidade. O pensamento cognitivo também erra quando é parcial, ou seja, não evita as catexias desiderativas ou quando lhe "falta integridade para recorrer a todos os caminhos possíveis". Entretanto, o tipo de erro mais interessante reside numa espécie constatada pelo pensamento crítico. De acordo com Freud, as contradições lógicas decorrentes de um processo cogitativo incorreto levam ao desprazer devido à quantidade de energia acumulada para proteger as regras biológicas ser liberada. $\mathrm{O}$ interesse está na novidade que ele apresenta em relação aos anteriores. Neles, o desprazer poderia surgir a partir de uma ação sugerida pelo processo de pensamento. Aqui, a produção do desprazer está diretamente vinculada ao pensamento e não, como no anterior, às suas conseqüências: são contradições lógicas.

Ora, é surpreendente em relação aos pressupostos e ao desenvolvimento do "Projeto" que Freud se refira às contradições lógicas para justificar a existência das regras biológicas. Como já foi assinalado, elas são justificadas a partir de critérios puramente pragmáticos: é a evolução, guiada pelo desprazer, que se responsabiliza pela sua gênese. ${ }^{82} \mathrm{Se}$ a contradição provoca desprazer, ou mais precisamente, o reconhecimento de que se cometeu uma, seria mais fácil afirmar que a sua origem também remonta a ações que terminaram por provocar o aumento de quantidades em ômega. Em outras palavras, essas afirmações de Freud seriam muito elípticas, não revelando toda a complexidade de relações que existem entre pensamento e ação.

Segundo o texto, só se pode conceber a ação como a "catexização total daquelas representações motoras que foram destacadas durante o processo cognitivo e talvez aquelas que faziam parte da porção arbitrária da ação específica (caso tenha havido um estado de expectativa)" ${ }^{83}$ Essa forma de entender a ação estabelece de imediato uma vinculação entre ela, o pensamento, a experiência de sa-

(82) Freud parece adotar a crença de que a lógica resulta das ações e experiências do sujeito.

(83) Ibid., ESB, p. 505; SE, p. 386. 
tisfação e os sinais de qualidade. Vimos que a forma mais avançada de pensamento é aquela acompanhada desses sinais. Portanto, deve existir uma categoria de ação que decorra exatamente do pensamento e que possa, por conseguinte, ser adequadamente justificada através da fala (justificada no sentido que Freud usa quando afirma que "a compulsão histérica não é justificada adequadamente"). Por outro lado, também assinalamos que a coisa tem a natureza de uma "referência", e que a experiência de satisfação, por ser produzida através da ajuda de um outro, é convertida na fonte de todas as motivações morais. O que leva a pensar que, quando há adequação entre fala e ação, ela decorre de uma referência simultânea ao sujeito e ao objeto motivada pelo fato da representação do objeto ser vista como um complexo coisa-predicado da coisa, onde há contribuições tanto do sujeito corno do objeto. A dupla referência permite que o sujeito através da sua fala entenda o que está ocorrendo e que seja compreendido pelo outro que o formou enquanto sujeito de fala; nesse sentido, Freud afirma que as ações "não estão associadas com as representações da fala, antes pelo contrário, servem em parte às finalidades dessa associação". ${ }^{84}$

A presente leitura do texto freudiano se torna mais verossímil ao examinarmos os processos primários que podem irromper no ego. Iniciaremos pelo estudo dos sonhos e finalizaremos pelo exame da histeria, ou seja, começaremos pelo normal para terminar no neurótico.

A condição para que o sonho surja é a existência de catexias insuficientes no ego. Elas ocorrem porque o sonho é produzido durante o estado de sono no qual o organismo está livre do acúmulo de quantidades. A descarga do ego torna desnecessário o mecanismo de atenção, ou seja, as inibições impostas pelo ego para evitar alucinações e, por conseqüência, o desprazer. Em outras palavras, o que torna possívei o sonho é o fato das quantidades envolvidas serem muito pequenas, porém não nuias. Se o fossem, não haveria sonhos. O que explica, em parte, porque as imagens oníricas aparecem como contraditórias ou absurd̉as. Como as inibições não estão presentes, $o$ curso seguido pelas representações é puramente associativo, pré-verbal. ${ }^{85}$ Vimos que essas vias associativas se formaram a partir de experiências de satisfação. Logo, a finalidade do sonho é realizar desejos. A falta de inibição também expiica o caráter alucinatório das

(84) Ibid., ESB, p. 506; SE, p. 387.

(85) Ibid., ESB, pp. 444-448; SE, pp. 336-339. 
imagens do sonho; Freud afirma: "fechado os olhos, se alucina", "aberto os olhos, se pensa em palavras". ${ }^{86}$ Assim, o sonho é visto como um processo muito antigo que escapou à experiência biológica por envolver quantidades muito pequenas e seguir vias já traçadas, sem as modificar. Isso permite inferir que os processos primários também teriam sido de caráter alucinatório; aliás, essa foi a razão de darem lugar aos procęssos secundários.

Por que não tomamos consciência de que os nossos sonhos repetem velhas experiências de satisfação? Segundo Freud, porque o "significado do sonho está encoberto" pelos mesmos processos que encontramos nas neuroses de defesa. ${ }^{87} \mathrm{~A}$ resposta dada exclui razões do tipo: defeitos da consciência, falta de atenção, etc. Pois, a consciência, de acordo com o texto, não está limitada ao ego. Por conseguinte, não se deve tomar como equivalentes processos primários e processos não conscientes. A consciência é uma "leitora" que se pode agregar a qualquer processo, primário ou secundário. No caminho da consciência não se encontra a chave que decifra o sonho; ela está na revelação dos processos presentes na formação onírica. Temos consciência de alguns pontos do sonho, mas outros permanecem não conscientes. Para exempiificar, Freud recorre a um de seus sonhos, o chamado "sonho de Irma". ${ }^{88}$

Suponhamos que A, B, C e D sejam representações presentes no sonho cujas referências são:

(A) representação onírica consciente que leva a B ("Otto aplicou em Irma uma injeção de propil");

(B) representação da realização do desejo que não se torna consciente ("conversa com Fliess sobre o quimismo sexual");

(C) representação que adquiriu nitidez alucinatória porque se encontra no caminho que leva de B até D e está simultaneamente presente ("a fórmula da trimetilamina");

(D) representação catexizada não consciente que leva de $\mathrm{A}$ para C ("a doença de Irma é de natureza sexual").

No caso presente, C se torna consciente pela pressão simultânea das direções AC e DC, ou seja, pela ocorrência de um "deslo-

(86) Ibid., ESB, p. 447: SE, p. 339. Portanto, o mesmo conteúdo mnêmico pode produzir efeitos distintos dependendo do estado do organismo.

(87) Ibid., ESB, p. 449; SE, p. 341. A resposta freudiana não nos deve levar na direção de supor que ele já possui uma teoria que conceba o sonho como uma formação de compromisso. As afirmações seguintes tornarão isto evidente.

(88) Ibid., ESB, pp. 450-451; SE, pp. 341-342. 
camento" de quantidades de B e de D para C, que assim se torna quantitativamente superior e consciente. A representação B é inferior quantitativamente ao desejo que ela substitui; em outras palavras, "o desejo é sempre mais intenso que a representação desiderativa que o vai substituir". ${ }^{89}$ Sabemos que a coisa tem uma catexia sempre superior à dos seus predicados. Contudo, Freud não dá nenhuma indicação sobre a origem do deslocamento, limitando-se a descrever a sua ocorrência e a afirmar que ele também ocorre nos "atos falhos". 90 Tampouco, ficamos sabendo que "experiência antiga de satisfação" foi percorrida por esse sonho. Entretanto, não é difícil constatar que a substituição de um predicado por outro $(C$ por B), além da omissão da coisa, acarreta a perda da "referência", isto é, a perda da inteligibilidade da narrativa do sonho, tanto para o sonhador como para um outro: não se consegue entender que desejo está sendo realizado (aliás, nem mesmo que se trata de uma realização de desejo) quando se tem presente apenas A e C. No entanto, a dificuldade não parece desaparecer diante de toda a série A-BC-D. Por outro lado, em nenhum momento, Freud relaciona o conceito de deslocamento com o de defesa no caso do sonho.

$\mathrm{O}$ exame das neuroses se inicia pelo estudo da compulsão histérica. Ela caracteriza-se pela sua extraordinária freqüência na consciência sem que haja quaisquer justificativas a partir dos fatos presentes. O sujeito não consegue suprimi-la nem compreendê-la, tendo "plena consciência do caráter estranho da situação em que se encontra": aparecem inexplicavelmente estados afetivos intensos, inervações motoras, inibições. ${ }^{91}$ A situação aparece como extravagante para um outro; não se entende como aquela representação pode dar lugar a tais efeitos. Em resumo, a compulsão histérica é "incompreensível, incapaz de ser resolvida por atividade cogitativa e incongruente em sua estrutura". ${ }^{92}$

Freud afirma que "torná-la compreensível" é equivalente a desfazê-la, isto é, "ela é resolvida quando é explicada". 93 Sabemos

(89) Ibid., ESB, pp. 451-452; SE, p. 342.

(90) Ibid., ESB, p. 451; SE, p. 342. A suposição freudiana ultrapassa a sua possibilidade teórica de momento. Freud não possui uma teoria que possa justificar a sua afirmativa.

(91) Ibid., ESB, p. 458; SE, p. 347.

(92) Ibid., ESB, p. 458; SE, p. 348.

(93) Ibid., ESB, p. 459; SE, p. 348. Como veremos, a seguir, o termo "explicar" tem uma conotação fortemente semântica e não nomológica. 
que o lugar de sua resolução é a sessão analítica. O interesse, portanto, reside nas informações que ela propicia sobre as compulsões histéricas. Suponhamos, por exemplo, que A seja uma representação muito intensa que surge com grande freqüência na consciência e é sempre acompanhada de choro. No entanto, o indivíduo não sabe por que A o faz chorar. Acha a sua situação absurda, mas não consegue impedir o choro cada vez que $\mathrm{A}$ vem à sua consciência. Após a análise, ficamos sabendo que A é a descrição de uma circunstância acessória que ocorreu ao mesmo tempo que um outro evento, representado por B. Ora, B é com toda razão o motivo do choro; é compreensível para sujeito a relação que existe entre B e o choro, e é possível para ele combater os efeitos de B através de "um trabalho psíquico bem complicado". ${ }^{94}$

$\mathrm{O}$ fato de ter existido uma experiência em que se formaram $\mathrm{A}$ e B possibilitou, através de processos que iremos examinar, a substituição de B por A, ou seja, A se tornou um "símbolo de B". A partir daí, A passa a produzir efeitos "que não lhe são adequados". A principal diferença entre a formação de símbolos histéricos e a de normais está em que, no primeiro caso, o sujeito desconhece a associação A-B; aliás, B não desempenha nenhum papel na sua vida psíquica: "houve uma substituição total da coisa pelo símbolo". Como conseqüência, A adquire um caráter compulsivo enquanto B permanece recalcada. Segundo Freud, "a cada compulsão corresponde um recalque; a toda irrupção excessiva na consciência, há uma amnésia correspondente". ${ }^{95}$

Constatamos, portanto, que um dos efeitos do recalque está em tornar incompreensível para o sujeito a relação entre sua fala e a sua ação (no caso presente, a relação entre A e o choro). Daí, a relação aparecer como "inadequada", "absurda", "incompreensível".

Por outro lado, devemos levar em conta que os graus de adequação estão fixados pela prática da fala que se formou pela presença do outro na ação específica, ou seja, nas repetidas experiências de satisfação. O que indica que a nossa leitura da "coisa" como "referência" parece estar parcialmente justificada pelo próprio texto do "Projeto". Voltando ao exemplo, podemos perguntar: o que ocorreu no aparelho psíquico? Freud acredita que houve um erro na

(94) Ibid., ESB, p. 459; SE, p. 349. Esse trabalho é responsável pelo estabelecimento das diferenças entre as representações no ego.

(95) Ibid., ESB, p. 460; SE, p. 350. 
distribuição das quantidades de energia: o que se agregou a $\mathrm{A}$ se originou de $\mathrm{B}$ e lhe foi retirado através de deslocamento, ou seja, por meio de um processo primário. ${ }^{96}$

De novo temos uma descrição onde aparece o deslocamento. Contudo, sua presença aqui se deve ao processo de recalque. Podemos supor que, no caso dos sonhos, devido à retirada do mecanismo de atenção do ego, há uma volta ao processo primário: realização de velhas experiências de satisfação. Entretanto, no caso da histeria a sua ocorrência está condicionada ao recalque, o que sugere a questão: por que se produziu o recalque? Segundo o texto, a experiência clínica mostra que ele só afeta representações que provocam desprazer e que todas elas pertencem ao campo da sexualidade. Mas, por que não ocorreu, no caso presente, uma defesa cogitativa no ego? Em outras palavras, por que a representação não foi inibida? Para que ela o fosse, a representação deveria se referir a uma experiência vivida e compreendida pelo sujeito. Portanto, a ausência da defesa cogitativa está relacionada ao não preenchimento de pelo menos uma dessas condições. Podemos recolocar a questão em termos mais precisos: o que há nessas representações sexuais que as impede de serem vividas e/ou entendidas pelo sujeito quando ocorrem? Uma maior precisão pode ser alcançada quando se leva em conta que a condição "vivida" necessariamente tem de estar presente sob pena da experiência não poder ser nem mesmo considerada como sexual. Finalmente, a questão pode agora tomar a seguinte forma: o que há nas representações sexuais que as impede de serem entendidas pelo sujeito quando ocorrem? ${ }^{97}$

A resposta é aparentemente simples: há um atraso no desenvolvimento sexual em relação às outras funções do sujeito; ela aparece apenas na puberdade. ${ }^{98}$ Por conseguinte, o que faz com que uma recordação possa despertar um estado afetivo que ela não possuía quando foi vivenciada é o atraso no aparecimento da sexualidade. Este impede que ela seja entendida enquanto tal. Contudo, não se deve ver aí a crença de que "todos adolescentes levam em si o germe da histeria". Eles não apresentam, como os histéricos, uma "predisposição para a liberação sexual precoce". ${ }^{99}$ Esta fornece o

(96) Ibid., ESB, pp. 460-461; SE. p. 350.

(97) Ibid., ESB, p. 454; SE, p. 353.

(98) Ibid., ESB, p. 468; SE, p. 356.

(99) Ibid., ESB, pp. 468-469; SE, pp. 356-357. 
fator quantitativo necessário para inverter a relação entre representação e percepção. Em outras palavras, é o entendimento da recordação na puberdade que leva a uma grande liberação de quantidades no ego, dando origem a um processo primário. Como o ego ignorava que a representação apresentava esse potencial, ele "permitiu" a ocorrência de uma vivência alucinatória. A permissão decorre da ausência de inibição por parte do ego quando a representação se formou, pois ela se referia a uma vivência dotada de pouca intensidade afetiva. Para exemplificar tais processos, analisemos um caso apresentado no próprio "Projeto": o caso Emma. ${ }^{100}$

Emma sofria da compulsão de não poder entrar sozinha em uma loja. Ela justificava-se afirmando que, quando tinha doze anos, entrou numa loja e um dos vendedores riu do seu vestido; ato seguinte, ela sentiu-se atraída sexualmente por ele.

A relação entre a compulsão e a sua justificativa é inadequada - não se compreende por que a cena juvenil possa interferir no seu comportamento presente. Também é estranho que a compulsão só apareça quando ela está sozinha; nada sente quando entra numa loja acompanhada. A análise descobre que, antes da cena dos doze anos, existiu uma outra, anterior, aos oito anos, onde ela foi comprar doces e o confeiteiro beliscou os seus genitais através do vestido. Ela retornou uma segunda vez a essa confeitaria. Mais tarde, recriminou-se por ter voltado.

Podemos entender agora, a partir das duas cenas, como elas se combinaram para formar a compulsão. Quando entrou na loja, o fato de um dos vendedores estar rindo provocou, sem que ela tivesse consciência, a recordação da cena da confeitaria. A compreensão do seu caráter sexual a posteriori provocou um aumento na quantidade dessa representação, o que resultou numa alucinação. O resultado do processo foi o recalque e a transformação da excitação sexual em angústia. A liberação sexual se tornou consciente sob a forma de uma atração sexual pelo vendedor que ri. O estado de angústia ligou-se ao temor de que os vendedores pudessem repetir o atentado inicial. Contudo, o recalque provocou o deslocamento de quantidades da representação do atentado para a representação do vestido; e é este elemento comum às duas cenas, o vestido, que se transforma em um símbolo do atentado. A partir daí, se estabelece uma "conexão falsa": o vendedor ri do vestido e ela está atraída sexualmente

(100) Ibid., ESB, pp. 464-468; SE, pp. 353-356. 
por ele. Como resultado do recalque, a representação atentado perde a sua quantidade, estando fora do ego e, portanto, de qualquer processo cogitativo. Toda procura de recatexizá-la leva de novo ao recalque. ${ }^{101}$ Quais as conseqüências do recalque?

A privatização da fala de Emma. Ela perdeu simultaneamente a relação com o outro (o confeiteiro) e consigo mesma. No primeiro caso, a perda é dupla: ela não percebe mais o confeiteiro nem como objeto hostil (ele atentou contra Emma) nem como objeto a ser procurado (ela retornou à confeitaria). Portanto, há perda de si mesma porque ela não pode se reconhecer enquanto sujeito - o retorno à cena de agressão. Perder ambas as relações significa perder a "representação do objeto", ou seja, a relação entre a coisa e o seu predicado; em suma, perder a referência. O que acaba por torná-la incapaz de compreender, em relação a um certo conjunto de objetos, os objetos sexuais, as vinculações que passou a estabelecer entre sua ação e a sua fala. Em resumo, o recalque levou à perda da "autoreferência" e da "referência ao objeto" em um certo conjunto de enunciados que relacionam a sua fala à sua ação, tornando a sua compreensão impossível tanto para os outros como a fortiori, para ela mesma.

O caso também serve para mostrar por que Freud afirma que há uma analogia estreita entre sonho e sintoma neurótico. Nos dois casos ocorre um deslocaḿento. No primeiro, devido à retirada do mecanismo de atenção; no segundo, é a inversão quantitativa entre percepção e representação motivada pelo aparecimento tardio da sexualidade e, portanto, de compreensão de que uma vivência foi sexual.

Contudo, nada foi dito sobre a existência de recalque nos sonhos, o que coloca mais um problema para a teoria do "Projeto": estaremos certos ao atribuir ao recalque a perda da função de referência? Ela não resultaria também do recalque? Mas o que há nas velhas experiências de satisfação que mobilizaria o processo de defesa?

Entretanto, Freud não responde às questões acima. Existe um obstáculo a ser vencido. Sua teoria construiu o sonho e a neurose a

(101) A idéia de que a inversão quantitativa entre vivência e recordação é a única causa do recalque é falsa. Pois, a quantidade só aumenta porque se formaram representações contrastantes que tornaram a compreensão daquela cena uma representação carregada afetivamente. Em outras palavras, o efeito quantitativo resulta de um efeito de sentido. 
partir de duas vivências distintas, marcadas pela oposição quantidade interna/quantidade externa. O sonho está ligado ao desejo mas não sofre a ação do recalque, ele ocorre todos os dias em todos os homens. A histeria só conhece a vivência da dor, o atentado sexual: há recalque mas não há desejo. Ela traz em si mesma uma alteridade irredutível: a precocidade sexual dos neuróticos. Logo, é preciso esperar que essa máquina que fala, construída a partir do conceito de quantidade, seja desmontada, que a neurose obsessiva tome o lugar da histeria como paradigma de inteligibilidade dos processos anímicos de modo que sonho e sintoma deixem de apresentar entre si uma relação de analogia e passem a uma de identidade conceitual. Em resumo, que a máquina falante dê lugar à fala maquinal.

\section{BIBLIOGRAFIA}

Freud, S. (1950(1895)). "Projeto para uma Psicologia Científica", Edição Standard Brasileira, vol. I, Rio de Janeiro: Imago Editora Ltda., 1977; SE, vol. I, London: Hogarth Press, 1966. 